Jurnal Akuntansi dan Bisnis: Jurnal Program studi Akuntansi, 6 (1) Mei 2020.

ISSN 2443-3071 (Print) ISSN 2503-0337 (Online). DOI: 10.31289/jab.v6i1.2922

JURNAL AKUNTANSI DAN BISNIS

Jurnal Program Studi Akuntansi

Available online http://ojs.uma.ac.id/index.php/jurnalakundanbisnis

\title{
PENGARUH GOOD CORPORATE GOVERNANCE TERHADAP CORPORATE SOCIAL RESPONSIBILITY PADA PERUSAHAAN SUB SEKTOR TRANSPORTASI YANG TERDAFTAR DI BURSA EFEK INDONESIA
}

\author{
Noriko Thasya $a^{*}$, Lisah $^{a}$, Angeline ${ }^{a}$, Natasyah Gozal ${ }^{a}$, Veronica ${ }^{a}$ \\ a Universitas Prima Indonesia
}

Diterima September 2019; Disetujui Desember 2019; Dipublikasikan Mei 2020

\begin{abstract}
Abstrak
Penelitian ini bertujuan untuk menguji pengaruh Good Corporate Governance terhadap Corporate Sosial Responsibility. Data yang digunakan dalam bentuk laporan tahunan yang diterbitkan oleh perusahaan di Situs Bursa Efek Indonesia. Populasi yang digunakan adalah perusahaan sub sektor transportasi yang terdaftar di Bursa Efek Indonesia Periode 2014 - 2018 yang berjumlah 37 perusahaan. Purposive sampling digunakan dalam penelitian ini sehingga diperoleh 8 perusahaan yang dijadikan sampel penelitian. Teknik analisis data menggunakan analisis regresi linear berganda dengan bantuan SPSS versi 25. Hasil penelitian ini menunjukkan bahwa Komite Audit berpengaruh negatif terhadap Corporate Sosial Responsibility, Dewan Komisaris tidak berpengaruh terhadap Corporate Sosial Responsibility, Kepemilikan Institusional berpengaruh negatif terhadap Corporate Sosial Responsibility, dan Komisaris Independen tidak berpengaruh terhadap Corporate Sosial Responsibility.
\end{abstract}

Kata Kunci: Good Corporate Governance, Komite Audit, Dewan Komisaris, Kepemilikan Institusional, Komisaris Independen, Corporate Sosial Responsibility.

\begin{abstract}
This study aims to examine the effect of good corporate governance on corporate social responsibility. The Data that used in this research are all form of annual reports published by companies on the Indonesia Stock Exchange website. The population used is transportation sub Sector Company listed on the Indonesia Stock Exchange for the period 2014-2018 which amounted to 37 companies. Purposive sampling is used in this research to obtain 8 companies as research sample. The data were analyzed using multiple regression analysis using SPSS Version 25. The results of the research showed audit committee negatively influence on the corporate social responsibility, the board of commissioners has no influence on the corporate social responsibility, the institutional ownership negatively affected on the corporate social responsibility, and the independent commissioner no impact on the corporate social responsibility.
\end{abstract}

Keyword: Good Corporate Responsibility, Audite Committee, the Board of Commissioners, Institusional Ownership, Independent Commissioner, Corporate Sosial Responsibility.

How To Cite: Noriko Thasya, Lisah, Angeline, Natasyah Gozal, Veronica (2020) Pengaruh Good Corporate Governance Terhadap Corporate Social Responsibility Pada Perusahaan Sub Sektor Transportasi Yang Terdaftar Di Bursa Efek Indonesia. Jurnal Akuntansi dan Bisnis: Jurnal Program Studi Akuntansi, 6 (1): 59 - 65

* email: norikothasya@gmail.com 


\section{PENDAHULUAN}

Sektor transportasi di Indonesia merupakan pelayanan jasa dan sumber utama dalam kegiatan ekonomi yang pada akhirnya akan menentukan tingkat kualitas daya saing suatu perekonomian, tersedianya sarana dan prasarana yang memadai, layak, efektif, efesien dan berkembangnya industri jasa pada sektor transportasi darat, laut dan udara akan menentukan kecepatan pertumbuhan perekonomian Indonesia untuk mengatasi pesaingan global yang semakin tinggi. Suatu negara yang memiliki perekomian yang baik pasti didukung dengan tingkat pembangunan infrastruktur yang baik salah satunya yaitu sektor transportasi. Perkembangan perusahaan senantiasa dihadapkan pada tanggungjawab yang berpijak pada tiga garis dasar, yaitu ekonomi, sosial khususnya kesejahteraan masyarakat dan pemeliharan serta pelestarian lingkungan (Siagian, 2010). Oleh sebab itu, diharapkan dalam membantu pembangunan perekonomian, para stakeholder yaitu pemerintah, dunia usaha dan masyarakat dapat saling menguntungkan, saling berkontribusi dan dapat memiliki hubungan yang harmonis (Setyarini dan Paramitha, 2011). Dalam hal ini dunia usaha memegang peran yang sangat penting dalam sistem ekonomi dengan cara turut berpartisipasi dalam kegiatan sosial maupun kegiatan apapun yang bertujuan untuk mengembangkan lingkungan, meningkatkan dan membangun perekonomian serta mensejahterahkan kehidupan masyarakat agar lebih baik lagi atau dapat disebutkan dengan Corporate Social Responsibility (CSR).

Seperti halnya di tetapkan dalam UU no. 40 tahun 2007 tentang perseroan terbatas pasal 74 , bahwa perseroan wajib melaksanakan tanggung jawab sosial dan lingkungan, dan jika perusahaan tidak melaksanakannya akan diberi sangsi sesuai dengan peraturan perundang-undangan. Corporate social responsibility atau Tanggung jawab sosial perusahaan adalah suatu program kepedulian dari perusahaan terhadap masyarakat dan lingkungan sekitar, kontribusi yang diberikan dapat mendorong pemberdayaan masyarakat. Keterlibatan sosial perusahaan ini sangat diharuskan, dikarenakan melalui program ini dapat mendapatkan berbagai keuntungan baik bagi pihak perusahaan maupun masyarakat, seperti dalam hal mendapat citra positif dari masyarakat sehingga perusahaan dapat keuntungan jangka panjang, ataupun dalam hal terbangkitkannya kesadaran perusahaan akan pentingnya lingkungan sosial yang baik, lingkungan sosial yang baik dapat mendukung keberhasilan bisnis untuk waktu yang panjang (Keraf, 1998). Adapun tujuan Penelitian ini adalah untuk memguji apakah terdapat pengaruh baik secara parsial maupun simultan good corporate governance terhadap pengungkapan corporare social responsibility.

\section{METODE PENELITIAN}

Penelitian ini mengunakan metode pendekatan kuantitatif. Metode pengumpulan data yang dilakukan dalam penelitian ini adalah metode tidak langsung yaitu data diperoleh dengan mendownload dari Bursa Efek Indonesia dan website perusahaan yang dijadikan sampel. Jenis data yang digunakan dalam penelitian ini adalah data sekunder yang bersumber dari website resmi Bursa Efek Indonesia dan website perusahaan dalam periode 2014 - 2018. Populasi perusahaan sub sector transportasi yang terdaftar di Bursa Efek Indonesia adalah 37 perusahaan. Sampel penelitian diambil dengan metode purposive sampling, yaitu teknik penentuan sampel dengan kriteria tertentu (Hasan. 2002). Berdasarkan kriteria tertentu, dihasilkan sampel penelitian yang berjumlah 8 perusahaan.

\section{HASIL DAN PEMBAHASAN}




\section{Uji Asumsi Klasik}

Pengujian asumsi klasik yang dipakai dalam penelitian ini adalah sebagai berikut: Uji Normalitas, Uji Multikolinearitas, Uji Heteroskedastisitas dan Uji Autokorelasi. Tabel 2 menunjukkan nilai Tolerance Komite Audit 0,941 > 0.1, nilai VIF 1,063<10, nilai Tolerance Dewan Komisaris 0,906 > 0,1, nilai VIF 1,104 < 10, nilai Tolerance Kepemilikan Institusional $0,738>0,1$, nilai VIF $1,354<10$, nilai Tolerance Komisaris Independen $0,751>0,1$, nilai VIF $1,331<10$. Maka tidak terdapat multikolinearitas antar variable independen.

Tabel 1 Uji Normalitas

$\begin{array}{cc}\text { Keterangan } & \text { Value } \\ \mathrm{N} & 40 \\ \text { Mean } & .0000000 \\ \text { Std. Deviation } & .04596766 \\ \text { Absolute } & .101 \\ \text { Positive } & .057 \\ \text { Negative } & -.101 \\ \text { ogorov-Smirnov Z } & .638 \\ \text { mp. Sig. (2-tailed) } & .810\end{array}$

Tabel 2 Uji Multikolinearitas

\begin{tabular}{llcccc}
\hline & & \multicolumn{2}{c}{ Unstandardized Coefficients } & \multicolumn{2}{c}{ Collinearity Statistics } \\
\cline { 3 - 6 } Model & & $\mathrm{B}$ & Std. Error & Tolerance & VIF \\
\hline 1 & (Constant) & .425 & .076 & & \\
& Komite_audit & -.081 & .030 & .941 & 1.063 \\
& Dewan_komisaris & .007 & .004 & .906 & 1.104 \\
& Kepemilikan_inst & -.002 & .000 & .738 & 1.354 \\
& Komisaris_independen & .000 & .001 & .751 & 1.331 \\
\hline
\end{tabular}

Tabel 3. Uji Autokorelasi

\begin{tabular}{cccccc}
\hline Model & $\mathrm{R}$ & R Square & $\begin{array}{c}\text { Adjusted R } \\
\text { Square }\end{array}$ & $\begin{array}{c}\text { Std. Error of the } \\
\text { Estimate }\end{array}$ & Durbin-Watson \\
\hline 1 & $.757^{\mathrm{a}}$ & .573 & .524 & .04852 & 1.820 \\
\hline
\end{tabular}

Hasil uji autokorelasi sebelum transformasi menunjukkan nilai Durbin Watson sebesar 1.820 sedangkan dalam tabel DW pada taraf nyata $5 \%$ dengan " $\mathrm{k}$ " $=4$ (Variabel Independen, tidak termasuk variabel dependen) dan $n=40$ didapatkan nilai $\mathrm{d}_{\mathrm{L}}=1,2848$ dan $\mathrm{d}_{\mathrm{U}}=1,7209$. Maka dengan kriteria $\mathrm{d}_{U}<\mathrm{DW}<4$ - $\mathrm{d}_{\mathrm{U}}$ atau 1,7209 $<1,820<2,2791$ maka tidak terdapat autokorelasi dalam data yang digunakan.

Tabel 4 Uji Heteroskedastisitas Uji Glejser

\begin{tabular}{cccccc}
\hline & \multicolumn{2}{c}{$\begin{array}{l}\text { Unstandardized } \\
\text { Coefficients }\end{array}$} & \multicolumn{2}{c}{$\begin{array}{c}\text { Standardized } \\
\text { Coefficients }\end{array}$} \\
Model & $\mathrm{B}$ & Std. Error & Beta & $\mathrm{t}$ & Sig. \\
\hline (Constant) & .467 & .494 & & .946 & .351 \\
Komite_audit & -.257 & .196 & -.216 & -1.311 & .198 \\
Dewan_komisaris & .018 & .026 & .119 & .706 & .485 \\
Kepemilikan_inst & .000 & .003 & .019 & .102 & .919 \\
Komisaris_independen & .007 & .008 & .151 & .816 & .420 \\
\hline
\end{tabular}


Hasil uji Glejser pada tabel 4 menunjukkan nilai signifikan variabel independen, yaitu Komite Audit 0,198, Dewan Komisaris 0,485, Kepemilikan Institusional 0,919 dan Komisaris Independen 0,420. Seluruh nilai signifikan tersebut memiliki nilai yang lebih besar dari 0,05. Maka dapat disimpulkan tidak terjadi masalah heteroskedastisitas.

\section{Hasil Analisis Data Penelitian}

Analisis data penelitian dilakukan dengan analisis regresi linear berganda untuk mengetahui apakah variabel independen mempengaruhi variabel dependen.

Tabel 5 Analisis Regresi Linear Berganda

\begin{tabular}{|c|c|c|c|c|c|}
\hline \multirow{2}{*}{ Model } & \multicolumn{2}{|c|}{$\begin{array}{l}\text { Unstandardized } \\
\text { Coefficients }\end{array}$} & \multirow{2}{*}{$\begin{array}{l}\text { Standardized } \\
\text { Coefficients } \\
\text { Beta }\end{array}$} & \multirow[t]{2}{*}{$\mathrm{t}$} & \multirow[t]{2}{*}{ Sig. } \\
\hline & B & Std. Error & & & \\
\hline (Constant) & 0.425 & 0.076 & & 5.628 & 0 \\
\hline Komite_audit & -0.081 & 0.03 & -0.305 & -2.681 & 0.011 \\
\hline Dewan_komisaris & 0.007 & 0.004 & 0.216 & 1.86 & 0.071 \\
\hline Kepemilikan_inst & -0.002 & 0 & -0.547 & -4.259 & 0 \\
\hline Komisaris_independen & 0 & 0.001 & -0.098 & -0.772 & 0.446 \\
\hline
\end{tabular}

Dari Tabel 6 dibawah dapat diperoleh hasil analisis regresi yang terbentuk adalah sebagai berikut : CSR $=0,425-0,081$ Komite audit $+0,007$ Dewan Komisaris - 0,002 Kepemilikan Institusional + 0,000 Komisaris Independen

Nilai Konstanta (a) menunjukkan bahwa apabila variabel independen bernilai konstan, maka nilai CSR sebesar 0,425. Variabel Komite Audit menunjukkan bahwa setiap kenaikan Komite Audit sebesar 1 satuan, maka CSR mengalami penurunan sebesar 0,081 dengan asumsi variabel lain tetap. Variabel Dewan komisaris menunjukkan bahwa setiap kenaikan Dewan Komisaris sebesar 1 satuan maka CSR mengalami kenaikan sebesar 0,007 dengan asumsi variabel lain tetap. Variabel Kepemilikan Institusinal menunjukkan setiap kenaikan Kepemilikan Institusional sebesar 1 satuan maka CSR mengalami penurunan sebesar 0,002 dengan asumsi variabel lain tetap. Variabel Komisaris Independen menunjukkan setiap kenaikan Komisaris Independen sebesar 1 satuan maka CSR mengalami kenaikan sebesar 0,000 dengan asumsi variabel lain tetap.

Tabel 6 Uji Hipotesis Koefisien Determinasi

\begin{tabular}{lllll}
\hline Model & R & R Square & Adjusted R Square & Std. Error of the Estimate \\
1 & $.757^{\mathrm{a}}$ & .573 & .524 & .04852 \\
\hline
\end{tabular}

Pada Tabel 6 diperoleh nilai Adjusted $\mathrm{R}^{2}$ adalah 0,524, ini berarti variabel independen yaitu Komite Audit, Dewan Komisaris, Kepemilikan Institusional dan Komisaris Independen mempengaruhi variabel dependen yaitu Corporate Social Responsibility sebesar 52,4\%. Sisanya 47,6\% dipengaruhi oleh variabel lain seperti kepemilikan manajerial, ukuran perusahaan, probabilitas, earning management, profile perusahaan dan leverage.

Tabel 7 Pengujian Secara Simultan (Uji F) ANOVA

\begin{tabular}{lllllll}
\hline Model & Sum of Squares & df & Mean Square & F & Sig. \\
\hline
\end{tabular}




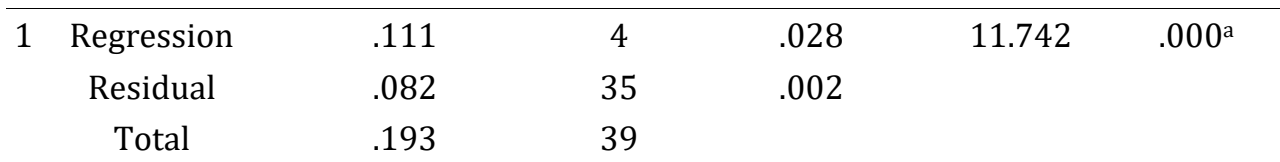

Pada Tabel 7, diperoleh nilai $F_{\text {hitung }}$ sebesar 11,742 sedangkan $F_{\text {tabel }}$ sebesar 2,64 yang dilihat pada tabel $\mathrm{N} 1=4$ dan $\mathrm{N} 2=35$. Berdasarkan nilai di atas ketahui nilai $\mathrm{F}_{\text {hitung }}$ $>$ Ftabel yaitu 11,742 > 2,64 dan nilai signifikasi sebesar 0,000 $<0,05$ yang berarti variabel Komite Audit, Dewan Komisaris, Kepemilikan Institusional dan Komisaris Independen secara simultan berpengaruh signifikan terhadap variabel Corporate Social Responsibility.

Nilai tabel pada probabilitas 0,05 dan derajat bebas 35 adalah 2,03011. Berdasarkan hasil uji pada tabel 8 dan nilai tabel maka dapat dijelaskan sebagai berikut :

Tabel 8 Pengujian Secara Parsial (Uji T)

\begin{tabular}{|c|c|c|c|c|c|}
\hline \multirow[b]{2}{*}{ Model } & \multicolumn{2}{|c|}{$\begin{array}{l}\text { Unstandardized } \\
\text { Coefficients }\end{array}$} & \multirow{2}{*}{$\begin{array}{c}\text { Standardized } \\
\text { Coefficients } \\
\text { Beta }\end{array}$} & \multirow[b]{2}{*}{$\mathrm{t}$} & \multirow[b]{2}{*}{ Sig. } \\
\hline & $\mathrm{B}$ & Std. Error & & & \\
\hline (Constant) & .425 & .076 & & 5.628 & .000 \\
\hline Komite_audit & -.081 & .030 & -.305 & -2.681 & .011 \\
\hline Dewan_komisaris & .007 & .004 & .216 & 1.860 & .071 \\
\hline Kepemilikan_inst & -.002 & .000 & -.547 & -4.259 & .000 \\
\hline Komisaris_independen & .000 & .001 & -.098 & -.772 & .446 \\
\hline
\end{tabular}

Pengaruh Komite Audit Terhadap Pengungkapan Corporate Social Responsibility (CSR).

Variabel Komite Audit memiliki nilai thitung sebesar -2,681 yang mana lebih besar dari tabel $(-2,681>-2,03011)$ dengan nilai signifikasi $0,011<0,05$. Ini berarti variabel Komite Audit berpengaruh secara negatif terhadap variabel CSR(H1 diterima). Hal ini sejalan dengan hasil penelitian Wiyuda dan Pramono (2017) yang menemukan adanya pengaruh negatif terhadap Corporate Social Responsibility. Hasil penelitian ini menunjukkan semakin sedikit jumlah anggota audit, akan lebih baik pengaruhnya terhadap luas pengungkapan Corporate Social Responsibility. Namun tidak mendukung hasil penelitian Untoro dan Zulaikha (2013) yang menunjukkan komite audit tidak berpengaruh terhadap luas pengungkapan Corporate Social Responsibility. Penelitian ini juga bertolak belakang dengan hasil yang diperoleh Fatimah, dkk (2016) dimana komite audit berpengaruh positif terhadap Corporate Social Responsibility.

\section{Pengaruh Dewan Komisaris. Terhadap Pengungkapan Corporate Social Responsibility (CSR).}

Variabel Dewan Komisaris memiliki nilai thitung sebesar 1,860 yang mana lebih kecil dari tabel $(1,860<2,03011)$ dengan nilai signifikasi $0,071>0,05$. Ini berarti variabel Dewan Komisaris tidak berpengaruh terhadap variabel CSR (H2 ditolak). Hal ini sejalan dengan hasil penelitian Paramita dan Marsono (2014). Berbeda dengan hasil penelitian Ramdhaningsih dan Utama (2013) yang menemukan dewan komisaris berpengaruh negatif dan tidak signifikan terhadap pengungkapan CSR. Hasil penelitian ini tidak sejalan dengan penelitian yang dilakukan oleh Hutapea dan Malau (2018) yang menunjukkan dewan komisaris berpengaruh positif signifikan terhadap Corporate Social Responsibility.

Pengaruh Kepemilikan Institusional Terhadap Pengungkapan Corporate Social Responsibility (CSR). 
Variabel Kepemilikan Institusional memiliki nilai thitung sebesar $-4,259$ yang mana lebih besar dari tabel $(-4,259>-2,03011)$ dengan nilai signifikasi $0,000<0,05$. Ini berarti variabel Kepemilikan Institusional berpengaruh secara negatif terhadap variabelCSR(H3 diterima). Hasil ini mendukung penelitian Prastuti dan Budiasih (2018). Rata-rata kepemilikan institusional dalam perusahaan sampel ialah saham mayoritas, hal ini menyebabkan kepentingan saham minoritas akan diabaikan karena investor institusional mayoritas cenderung berkompromi dengan pihak manajemen. Penelitian ini tidak sejalan dengan hasil penelitian Wiyuda dan Pramono (2017) yang menemukan kepemilikan institusional berpengaruh terhadap CSR.

\section{Pengaruh Komisaris Independen Terhadap Pengungkapan Corporate Social Responsibility (CSR).}

Variabel Komisaris Independen memiliki nilai thitung sebesar $-0,772$ yang mana lebih kecil dari tabel $(-0,772<-2,03011)$ dengan nilai signifikasi $0,446>0,05$. Ini berarti variabel Komisaris Independen tidak berpengaruh terhadap variabel CSR(H4 ditolak). Hasil ini sejalan dengan penelitian Paramita dan Marsono (2014) yang menyatakan adanya kemungkinan komisaris independen tidak mempengaruhi pengambilan keputusan karena tidak terlibat dalam operasional rutin perusahaan. Hasil yang berbeda ditunjukan oleh penelitian Nugroho (2016), yaitu komisaris independen berpengaruh terhadap pengungkapan Corporate Social Responsibility.

\section{SIMPULAN}

Berdasarkan hasil penelitian yang telah dilakukan oleh peneliti , maka kesimpulan yang dapat diambil oleh peneliti adalahkomite audit dan kepemilikan institusional berpengaruh secara negatif terhadap corporate social responsibility pada perusahaan transportasi yang terdaftar di Bursa Efek Indonesia periode 2014-2018. Sedangkan dewan komisaris dan komisaris independen tidak berpengaruh terhadap corporate social responsibility pada perusahaan transportasi yang terdaftar di Bursa Efek Indonesia periode 2014-2018.Komite Audit, Dewan Komisaris, Kepemilikan Institusional dan Komisaris Independen berpengaruh secara simultan terhadap Corporate social responsibility, nilai koefisiennya ialah 52,4\%

\section{DAFTAR PUSTAKA}

Fatimah, Siti, Makhdalena, dan Fenny Trisnawati. 2016. Pengaruh Komisaris Independen dan Komite Audit Terhadap Pengungkapan Corporate Social Responsibility Perusahaan Pertambangan di Bursa Efek Indonesia Periode 2012 s.d 2014. Jurnal Online Mahasiswa, Fakultas Keguruan dan Ilmu Pendidikan, Universitas Riau, 3 (2): 1-11.

Hutapea, Herti Diana, dan Elissa Lolita Malau. 2018. Pengaruh Praktek Good Corporate Governance (GCG) Terhadap Pengungkapan Corporate Social Responsibility (Studi Kasus Perusahaan Perbankan Yang Terdaftar di Bursa Efek Indonesia). Jurnal Ilmiah Skylandsea, 2 (2): 278-291.

Nilasari, Ervika. 2015. Pengaruh Profitabilitas, Kepemilikan Institusional, Kepemilikan Asing dan Size Terhadap CSR Disclosure Perusahaan Tambang (Mining Sector) Yang Melakukan Listing di Bursa Efek Indonesia Tahun 2010-2012. Skripsi. Fakultas Ekonomi dan Bisnis Universitas Dian Nuswantoro, Semarang, 1-20.

Nugroho, Ismoyo Adi. (2016). Pengaruh Karakteristik Perusahaan dan Corporate Governance Terhadap Pengungkapan Corporate Social Responsibility Pada Perusahaan Manufaktur di BEI Tahun 20102014. Skripsi. Fakultas Ekonomi dan Bisnis, Universitas Muhammadiyah Surakarta, 1-13.

Paramita, Andina Dwi, dan Marsono. 2014. Pengaruh Karakteristik Corporate Governance Terhadap Luas Pengungkapan Corporate Social Responsibility. Diponegoro Journal Of Accounting, 3 (1): 1-15.

Prastuti, Ni Ketut Karlina dan I Gusti Ayu Nyoman Budiasih. 2015. Pengaruh Good Corporate Governance Pada Nilai Perusahaan Dengan Moderasi Corporate Social Responsibility. E-Jurnal Akuntansi Universitas Udayana, 13 (1): 114-129. 
Priantana, Riha Dedi dan Ade Yustian. 2011. Pengaruh Struktur Good Corporate Governance Terhadap Pengungkapan Corporate Social Responsibility Pada Perusahaan Keuangan Yang Terdaftar di Bursa Efek Indonesia. Jurnal Telaah \& Riset Akuntansi, 4 (1): 65-78.

Ramdhaningsih, Amalia, dan I Made Karya Utama. 2013. Pengaruh Indikator Good Corporate Governance dan Profitabilitas Pada Pengungkapan Corporate Social Responsibility.E-Jurnal Akuntansi Universitas Udayana, 3 (2): 368-386.

Sanjaya, Oi, Taufeni Taufik,, dan Al Azhar L. 2014. Pengaruh Good Corporate Governance, Profitabilitas, dan Ukuran Perusahaan Terhadap Pengungkapan Tanggung Jawab Sosial Perusahaan Pada Perusahaan Real Estate dan Property Yang Terdaftar di Bursa Efek Indonesia (2010 - 2011). Jurnal Online Mahasiswa, Fakultas Ekonomi, Universitas Riau, 1 (1): 1-15.

Sari, Ati Retna, Sutrisno, dan Eko Ganis Sukoharsono. 2013. Pengaruh Kepemilikan Institusional, Komposisi Dewan Komisaris, Kinerja Perusahaan Terhadap Luas Pengungkapan Corporate Social Responsibility di dalam Sustainability Report Pada Perusahaan Manufaktur Yang Terdaftar di BEI. Jurnal Aplikasi Manajemen, 11 (3): 481-491.

Setyarini, Yulia dan Melvie Paramitha. 2011. Pengaruh Mekanisme Good Corporate Governance Terhadap Corporate Social Responsibility. Jurnal Kewirausahaan, 5 (2): 10-17.

Terzaghi, Muhammad Titan. 2012. Pengaruh Earing Management dan Mekanisme Corporate Governance Terhadap Pengungkapan Tanggung Jawab Sosial Perusahaan Manufaktur Yang Terdaftar di Bursa Efek Indonesia. Jurnal Ekonomi dan Informasi Akuntansi (Jenius), 2 (1): 31-47.

Untoro, Dwi Arini dan Zulaikha. 2013. Pengaruh Karakteristik Good Corporate Governance (GCG) Terhadap Luas Pengungkapan Corporate Social Responsibility (CSR) di Indonesia. Diponegoro Journal Of Accounting, 2 (2): 1-11.

Wiyuda, Alang dan Hadi Pramono. 2017. Pengaruh Good Corporare Governance, Karakteristik Perusahaan Terhadap Luas Pengungkapan Corporate Social Responsibility Pada Perusahaan Terdaftar di BEI. Jurnal Ilmiah Akuntansi, XV (1): 12-25.

Yusran, Izza Ariqah R, Farida Titik Kristanti, dan Wiwin Aminah. 2018. Pengaruh Indikator Good Corporate Governance Terhadap Corporate Responsibility Disclosure (Studi Pada Perusahaan Manufaktur Yang Terdaftar di Bursa Efek Indonesia Periode 2011-2016). E-Proceeding of Management, 5 (1): 621-627 